\title{
WOJNY BAŁKAŃSKIE 1912-1913 PRZYCZYNĄ ROZWOJU NACJONALIZMU „GORACEGO” NA BAŁKANACH W XX WIEKU. ZARYS PROBLEMU
}

\author{
DANUTA GIBAS-KRZAK
}

\begin{abstract}
Danuta Gibas-Krzak, Wojny bałkańskie 1912-1913 przyczyna rozwoju nacjonalizmu , gorqcego” na Batkanach w XX wieku. Zarys problemu (The Balkan Wars 1912-1913 as a cause of the development of "hot nationalism" in the Balkans. The outline of the problem).
\end{abstract}

Balcanica Posnaniensia. Acta et studia, XIX, Poznań 2012, Wydawnictwo Instytutu Historii UAM, pp. 121-138, ISBN 978-83-63-047-17-7, ISSN 0239-4278. Polish text with a summary in English.

Danuta Gibas-Krzak, Uniwersytet Szczeciński, Wydział Humanistyczny, Katedra Badań nad Konfliktami i Pokojem.

\section{Wstęp}

Wojny bałkańskie 1912-1913 miały charakter wstępu do pełnego konfliktów zbrojnych i przemocy XX w., wprowadzając międzynarodową opinię publiczną w gorączkowy stan wojennej euforii, jak również rozprzestrzeniającego się ducha militaryzmu ${ }^{1}$. Upowszechniły się wówczas stygmatyzujące określenia dotyczące tego regionu, które weszły do słownictwa międzynarodowego. Jednym z nich jest „kocioł bałkański”, który oznacza zderzenie sprzecznych interesów, jak również wynikający z nich zamęt i chaos, stanowi także metaforyczne odbicie konglomeratu różnych konfliktów narodowościowych, sporów kulturowych i religijnych, groźnego wrzenia oraz wchodzenia w niebezpieczne reakcje polityczne, ideologiczne i etniczne ${ }^{2}$. Kolejne pojęcie: „bałkańska beczka prochu” podkreśla wybuchowy, gwałtowny charakter wydarzeń zachodzących na tym terytorium. Ukształtowany po zakończeniu Kongresu

${ }^{1}$ Trudno nie zgodzić się z Marią Todorovą, znaną bułgarską bałkanistką, która podkreśliła, że co najmniej od początku XX w. „widmo krąży po Europie - widmo Bałkanów”. Słusznie bowiem przyjęło się sądzić, że polityczny wiek XX rozpoczął się burzliwie właśnie w tym regionie, czego przykład stanowią wojny bałkańskie, zamach na arcyksięcia Ferdynanda, jak również wybuch I wojny światowej. Koniec XX w. na Bałkanach zaznaczył się wojną domową w Jugosławii, która niewątpliwie stanowiła egzystencjalną i polityczną katastrofę narodów oraz grup etnicznych państw byłej federacji jugosłowiańskiej, M. Todorova, Imaginarni Balkan, Beograd 1999, s. 15.

2 T. Wituch, Bałkany - szkic definicji, „Dzieje Najnowsze” 1998, R. XXX, nr 2, s. 139. 
Berlińskiego (1878 r.) termin „bałkanizacja”, który najpierw odnosił się do procesu stopniowego tworzenia się po rozpadzie Turcji nowych państw takich jak: Grecja, Serbia, Rumunia, Bułgaria i Czarnogóra, rozszerzył w czasie wojen bałkańskich swój zakres pojęciowy, obejmując fragmentację nacjonalistyczną (nie tylko na Bałkanach). Po I wojnie światowej stał się także synonimem napiętych stosunków między małymi, sąsiadującymi państwami, które wywołują niekończące się konflikty³.

Podczas I wojny bałkańskiej generalnie opinia publiczna na Zachodzie opowiadała się po stronie narodów słowiańskich w walce narodowowyzwoleńczej z Imperium Ottomańskim, nie zwracano natomiast szczególnej uwagi na zbrodnie i przestępstwa popełnione przez Słowian i Greków. W czasie II wojny bałkańskiej sytuacja uległa zmianie, bowiem Turcja nie była już głównym wrogiem, zaś w trakcie walk między niedawnymi sojusznikami, członkami Ligi Bałkańskiej, dochodziło do czystek etnicznych dokonywanych nie tylko na muzułmanach (Turkach, Albańczykach, Kosowarach), lecz także na chrześcijanach. Dla światowej opinii publicznej stało się oczywiste, iż bałkańska nienawiść stwarza poważne wyzwanie dla bezpieczeństwa w Europie ${ }^{4}$.

Celem niniejszej analizy jest zaprezentowanie hipotezy, iż konflikty na Bałkanach w XX w. łączą się ze sobą, zaś jednym ze skutków wojen bałkańskich stał się rozwój nowoczesnego nacjonalizmu, którego przejawem były okrucieństwa popełniane przez wszystkie walczące strony. Czystki etniczne występujące podczas tych wojen przyczyniły się do rozwoju kolejnych antagonizmów między narodami bałkańskimi. Należałoby zatem odpowiedzieć na pytanie: czy miały one odrębny charakter, czy też stanowiły tylko jeden ze stałych elementów wojny, tego swoistego karnawału śmierci, egzystencjalnej katastrofy, w której eksterminacja stała się sposobem ujarzmienia narodów?

Główny materiał źródłowy, który został wykorzystany w analizie, stanowią wspomnienia uczestników wojen bałkańskich oraz przekazy prasowe korespondentów wojennych, zawarte w raporcie Międzynarodowej Komisji Carnegiego, jak również opracowaniach: Mirosława Dymarskiego, Krzysztofa Stępnika, Andrzeja Malinowskiego, Józefa Lipkowskiego, Philippa Thera, Justina McCarthy’ego i Lwa Trockiego 5 .

${ }^{3}$ M. Koch, „My” $i$ „,Oni”, „Swój”, $i$ „Obcy”. Batkany XX wieku z perspektywy kolonialnej, „Porównania” 2009, nr 6, s. 79. W ocenie wielu naukowców termin „bałkanizacja” upowszechnił się na początku XX w., oznaczając dezintegrację polityczną, gospodarczą i kulturalną tego regionu, a także nieufność etniczną oraz chęć podporządkowania się silniejszemu, zewnętrznemu podmiotowi w stosunkach międzynarodowych, Ilić, M. Spasovski, Geopolityczna specyfika Bałkanów i etniczne terytorium Serbów, „Sprawy Narodowościowe” 1994, T. III, z. 2 (5), s. 136.

${ }^{4}$ The Other Balkan Wars. A 1913 Carnegie Endowment inquiry in retrospect with a new introduction and reflections on the present conflict by George F. Kennan, Washington 1993, op. cit., s. 6.

${ }^{5}$ M. Dymarski, Konflikty na Bałkanach w okresie ksztaltowania się państw narodowych $w$ XIX i na poczatku XX wieku, Wrocław 2010; K. Stępnik, Wojny batkańskie lat 1912-1913 w prasie polskiej. Korespondencje wojenne i komentarze polityczne, Lublin 2011; J. Mc Carthy, Death and Exile. The ethnic cleansing of Ottoman Muslims 1821-1922, Princeton 1995; A. Malinowski, Kwestia macedońska w Butgarii w latach 1878-1918, Torun 2006; J. Lipkowski, Wojna na Batkanach przez naocznego świadka i uczestnika wojny, Warszawa-Lublin-Łódź-Kraków 1915; P. Ther, Ciemna strona państw narodo- 


\section{Etnopolityczny charakter konfliktów bałkańskich}

Geopolityczna i geostrategiczna specyfika Półwyspu Bałkański przejawia się m.in. w występowaniu szczególnie niebezpiecznych, trudnych do opanowania konfliktów ${ }^{6}$. Ich źródeł należy szukać w spirali nienawiści między narodami tego regionu, która rozwijała się od początku XX w., a nawet w latach wcześniejszych.

Zdaniem Hueya L. Kostanicka, historycznie Bałkany były regionem niestabilnym, gdzie występowały napięcia i podboje, wynikające z kompleksu wzajemnych powiązań między geografią a historią w okresie panowania tureckiego - od XIV w. do początku XX w. Korzenie współczesnego nacjonalizmu, który determinuje dzieje państw bałkańskich, sięgają poprzednich stuleci ${ }^{7}$. Trzeba podkreślić, że wojny bałkańskie odegrały w jego rozwoju niebagatelną rolę, gdyż w ich wyniku wykształcił się specyficzny typ nacjonalizmu Wschodniego i zarazem ,gorącego”, który w odróżnieniu od nacjonalizmu Zachodu posiada negatywny, wręcz destrukcyjny charakter. Nie ma więc cech unifikacyjnych jak nacjonalizm na Zachodzie ${ }^{8}$, lecz wręcz przeciwnie jego celem jest wykreowanie nowych kultur, rywalizujących z już istniejącymi. Zdaniem Johna Plamenatza, nacjonalizm Wschodu jest ,jadowity” i „fanatyczny". Społeczeństwo nim dotknięte tkwi w skomplikowanych układach związków terytorialnych, rodowych, religijnych, posiada także tendencję do zbieżności między państwem a kulturą, stanowiącą istotę tego nacjonalizmu9. Jego „gorący” charakter ujawnia się w spektakularnych działaniach, podejmowanych w celu obrony interesu narodowego, które prowadzą do odrodzenia się wcześniej istniejącego antagoni$\mathrm{zmu}^{10}$. Tworząca się spirala konfliktu nie ma końca, nie może wrócić do fazy zero-

wych. Czystki etniczne w nowoczesnej Europie, Poznań 2012; L. Trotsky, The war correspondence of Leon Trotsky. The Balkan Wars 1912-13, New York - London - Montreal - Sydney 1991.

6 Więcej u: S. Šušić, Balkanski geopolitički košmar, Beograd 1995.

${ }^{7}$ H. L. Kostanick, The Geopolitics of the Balkans, [w:] Ch. and B. Jelavich, The Balkans in transition, Berkely- Los Angeles 1963, s. 1-2. Źródeł nowoczesnego nacjonalizmu na Bałkanach można doszukiwać się także w procesach historycznych, odwołując się do średniowiecznej genezy „Wielkiej Grecji” i „Wielkiej Bułgarii”, R. Komsalova, Srednjovekownyje arhetipy i balkanskije nacionalizmy v vojnah 1912-1913 gg, wystąpienie podczas międzynarodowej konferencji XII Balcanicum. U źródeł wspótczesnych konfliktów na Bałkanach. Wojny bałkańskie 1912-1913 i ich skutki, Poznań 28 września 2012 r. Z kolei Peter Sugar podkreślił, iż w XIX w. doszło do przebudzenia narodów bałkańskich, czego efektem było wykrystalizowanie się zjawiska ,nacjonalizmu kulturowego”. Podstawą do głoszenia haseł niepodległościowych stała się sfera aksjologiczna, odwołująca się do przeszłości, a nawet do wyobrażeń o charakterze mitycznym. Więcej u: Nationalism in Eastern Europe, eds. I. J. Lederer, P. F. Sugar, Washington 1969.

8 Zgodnie z definicją przedstawioną przez prof. S. Wojciechowskiego nacjonalizm Zachodu charakteryzuje kultury dojrzałe, posiada charakter unifikacyjny, jest związany z ideałami liberalizmu i demokracji. Określany jest jako „łagodny”, a nawet „,dobrotliwy”, S. Wojciechowski, Nacjonalizm w Europie Środkowo-Wschodniej, Wrocław 1999, s. 30.

${ }^{9}$ E. Kellner, Narody i nacjonalizm, Warszawa 2009, s. 198-199.

10 S. Wojciechowski, Nacjonalizm..., op. cit., 1999, s. 41. 
wej, zgodnie z definicją konfliktu etnicznego, w ten sposób starcia między narodami na Bałkanach przybierają charakter permanentny i nieskończony ${ }^{11}$.

Nacjonalizm ten zyskał specyficzny charakter, nieznany $w$ innych regionach Starego Kontynentu. Wynikał bowiem z pragnienia dominacji, dokonania terytorialnych podbojów oraz wielkościowych idei, które występowały w nowo powstałych państwach bałkańskich. Prof. Franciszek Gołembski podkreślił, iż nacjonalizmy bałkańskie, wsparte racjami kulturowymi, stały się źródłem niechęci, jak również wrogości między krajami graniczącymi ze sobą. Powodem konfliktów były przede wszystkim roszczenia terytorialne, których nie można było zaspokoić na drodze porozumienia ${ }^{12}$. Znalazły one natomiast odzwierciedlenie w marzeniach o potędze i budowie państw na zasadach wielkościowych, które zdominowały potrzeby zarówno władz, jak i społeczeństw w wielu państwach tego regionu, gdzie zrodziły się koncepcje: „Wielkiej Serbii”, „Wielkiej Bułgarii”, „Wielkiej Grecji”, czy „Wielkiej Albanii". Stanowily one dziedzictwo traktatu pokojowego w San Stefano w 1878 r., na mocy którego Turcja musiała uznać niepodległość Rumunii, Serbii i Czarnogóry (Albania zyskała ograniczoną autonomię administracyjną) ${ }^{13}$. Zgodnie $\mathrm{z}$ jego postanowieniami, Bułgaria miała być największym terytorialnie państwem bałkańskim, obejmując również znaczną część Macedonii. Wielkościowe marzenia Bułgarów nie zostały jednak spełnione, bowiem postanowień traktatu z San Stefano nie wprowadzono w życie. Księstwo Bułgarskie zaczęło więc poszukiwać takich aliansów, które umożliwiłyby spełnienie jego mocarstwowych dążeń. Podobne aspiracje dotyczące rozszerzenia terytorialnego państwa narodowego miały: Serbia, Rumunia i Grecja. Kolejne możliwości dla urzeczywistnienia tych dążeń pojawiły się podczas wojen bałkańskich. Szybkie pokonanie Turcji podczas I wojny bałkańskiej przez państwa Ligi Bałkańskiej (Bułgaria, Serbia, Grecja, Czarnogóra) ${ }^{14}$ nie doprowadziło do zaspokojenia roszczeń terytorialnych i ambicji politycznych ${ }^{15}$. Serbowie nie uzyskali dostępu do morza, natomiast suwerenna Albania, powołana do życia w wyniku wojen bałkańskich, stanowiła przeszkodę dla dążeń Serbii i Czarnogóry. I wreszcie bułgarskie aspiracje do Morza Egejskiego oraz spornej części Macedonii zaostrzyły i tak już skomplikowaną sytuację. W konsekwencji istniejących sporów, w końcu czerwca 1913 r., wybuchła II wojna bałkańska, zwana międzysojuszniczą. Bułgaria wystąpi-

${ }^{11}$ Idem, Konflikt etniczny jako forma konfliktu społecznego, „Sprawy Narodowościowe” 2002, z. 20, s. 92.

${ }^{12}$ F. Gołembski, Geokulturowe uwarunkowania stosunków politycznych na Bałkanach, [w:] Bałkany. Etnokulturowe podtoże konfliktów, red. W. Konarski, A. Koseski, Pułtusk 2006, s. 76.

${ }^{13}$ A. Koseski, Albania. Krótki zarys dziejów, Warszawa 1988, s. 41.

${ }^{14}$ Całkiem słusznie w ocenie niektórych badaczy bułgarskich, sukces sojuszu bałkańskiego należy uznać za „oszałamiający”, M. Stamowa, Na drodze do narodowego zjednoczenia narodu albańskiego (1878-1944), [w:] Integracja i tożsamość narodowa w Europie Środkowo-Wschodniej na przestrzeni dziejów, red. E. Znamierowska-Rakk, Warszawa 2007, s. 84.

${ }^{15} \mathrm{Na}$ fali tego zwycięstwa sojuszników Albania proklamowała niepodległość, chociaż nie była zainteresowana współdziałaniem z innymi państwami bałkańskimi. Niepodległe państwo albańskie posiadało granice, które kwestionowali jego sąsiedzi, co stanowiło zarzewie kolejnych konfliktów, H. Batowski, Z polityki międzynarodowej XX wieku. Wybór studiów z lat 1930-1975, Kraków 1979, s. 68. 
ła przeciwko Serbii, Czarnogórze i Grecji. Dodatkowo do starcia dołączyły Rumunia i Turcja, która miała nadzieję na odzyskanie części utraconych posiadłości. Na mocy pokoju zawartego w Bukareszcie 10 sierpnia 1913 r. Bułgarii odebrano większość nabytków terytorialnych uzyskanych w wyniku I wojny bałkańskiej, zaś Macedonia została podzielona na trzy części ${ }^{16}$. Dla Bułgarii II wojna bałkańska stanowiła katastrofę narodową, straciła bowiem na rzecz Turcji większą część Tracji Wschodniej z Adrianopolem i Lüleburgaz ${ }^{17}$.

Dlaczego mające najbardziej negatywne konsekwencje dla pokojowego współistnienia narodów i państw nacjonalizmy rozwinęły się zwłaszcza w tej części Europy? Jakie uwarunkowania musiały nastąpić, aby ujawniły się one szczególnie w czasie wojen bałkańskich, potęgując nienawiść między narodami, które dopiero wyzwoliły się spod jarzma tureckiego, uprzednio razem walcząc przeciwko Imperium Osmańskiemu?

Trzeba podkreślić, iż nowo powstałe państwa na Bałkanach nie były w stanie współpracować ze sobą na arenie międzynarodowej, pomimo krótkiego aliansu, jakim była Liga Bałkańska. Nagromadziło się wiele przyczyn, które pociągnęły ludzi do walki i popełniania przestępstw. Jak podkreślił prof. Mirosław Dymarski, cierpiące prześladowania, nędzę i upokorzenia narody bałkańskie nie zdołały uwolnić się od żądzy odwetu za krzywdy, których doświadczały od pokoleń. Zemsta często miała podłoże socjalne: uboga ludność chłopska zwracała się przeciwko bejom, właścicielom ziemskim, za ich łupieżcze daniny i wyzysk ${ }^{18}$, a następnie nienawiść ta przenosiła się na sąsiada innej religii czy narodowości.

Prof. Krzysztof Stępnik w świetnym opracowaniu, Wojny bałkańskie lat 1912-1913 w prasie polskiej. Korespondencje wojenne i komentarze polityczne, podkreślił wyjątkową rolę fenomenu nienawiści etnicznej, występującej między narodami słowiańskimi, jej całkowitą irracjonalność, gdyż ujawniła się ona w środowisku dotychczasowych sprzymierzeńców, a swoją gwałtownością i intensywnością przewyższała negatywne uczucia, którymi darzono Turków, Austriaków czy Węgrów ${ }^{19}$.

Należy zgodzić się z Philippem Therem, że pod względem totalności, techniki wojennej i brutalności wobec ludności cywilnej wojny bałkańskie stanowią swoiste preludium I wojny światowej. Chociaż działania militarne trwały krótko (w obu wojnach ok. pół roku), stanowiły jednak ważną cezurę w nowoczesnym sposobie prowa-

16 Podział, zgodnie z którym Macedonia Egejska weszła w skład Grecji, Macedonia Wardarska przypadła Serbii, a Macedonia Piryńska - Bułgarii, nadal obowiązuje. Po rozpadzie Jugosławii, pod koniec XX w., na terytorium Macedonii Wardarskiej powstała suwerenna Macedonia, obecnie funkcjonująca na arenie międzynarodowej jako Była Jugosłowiańska Republika Macedonii.

17 Nowy podział terytorialny między Bułgarią a Turcją nastąpił na mocy traktatu konstantynopolitańskiego, który został podpisany 29 września 1913 r., A. Giza, Ziemie macedońskie na przełomie XIX i XX wieku, Szczecin 1996, s. 132.

18 M. Dymarski, Konflikty na Bałkanach w okresie kształtowania się państw narodowych w XIX i na poczatku XX wieku, Wrocław 2010, s. 294.

${ }^{19}$ K. Stępnik, Wojny batkańskie lat 1912-1913 w prasie polskiej. Korespondencje wojenne i komentarze polityczne, Lublin 2011, s. 30. 
dzenia wojny. Stosunkowo dobrze uzbrojone armie walczyły jednak nie tylko przeciwko sobie, ale także z pełnym rozmysłem przeciwko ludności cywilnej, co znalazło potwierdzenie w raporcie Komisji Carnegiego. Jej członkowie po zakończeniu wojny wizytowali terytoria objęte walkami, opisując miejscowości zrównane z ziemią, akty przemocy oraz gwałty ${ }^{20}$. Komisja przygotowała obszerny raport, w którym przedstawiono wpływ wojen bałkańskich na los ludności cywilnej, potwierdzając, że wszystkie strony konfliktu łamały prawo i zwyczaje wojenne. Jedną z cech charakterystycznych tych wojen było to, iż prowadziły je nie tylko armie, ale również narody, które wzajemnie się mordowały, nakręcając spiralę nienawiści etnicznej ${ }^{21}$. Celem konfliktu zbrojnego, w ocenie autorów raportu, była „całkowita eksterminacja obcej populacji”. Miejscowości były nie tylko zdobywane, ale po prostu w znacznej części niszczone, zaś mieszkańcy wypędzani. Ci natomiast, którzy pozostali, narażeni byli na gwalty i morderstwa ${ }^{22}$. Bezwzględnie traktowano jeńców, którzy, jeśli nie zostali od razu zabici, to byli skazywani często na powolne konanie z głodu i chorób zakaźnych. Największe zbrodnie popełnione zostały przez oddziały nieregularne. Nie stwierdzono natomiast, aby były za nie bezpośrednio odpowiedzialne rządy oraz dowódcy, chociaż z pewnością władze (zwłaszcza wojskowe) tolerowały akty bezprawia, a czasami nawet do nich zachęcały ${ }^{23}$.

Podczas wojen bałkańskich chrześcijanie wspólnie przeciwstawiali się muzułmanom, ale, zdaniem międzynarodowych obserwatorów, to nie religia była główną motywacją tych wojen, lecz silny, agresywny nacjonalizm. Polityczno-militarnego przeciwnika traktowano jako nieprzejednanego wroga, którego należało całkowicie wytępić2 ${ }^{2}$. Przewodniczący Komisji Carnegiego, Constant d'Estournelles ocenił, że okrucieństwa przypisywane Turkom nie były większe niż te, które chrześcijanie popełniali na muzułmanach oraz na przedstawicielach tej samej religii, lecz innej narodowości ${ }^{25}$. Prześladowania, których dopuściło się państwo tureckie względem narodów bałkańskich, brak konsekwencji w działaniu wielkich mocarstw oraz przedłu-

${ }^{20}$ P. Ther, Ciemna strona państw narodowych. Czystki etniczne w nowoczesnej Europie, Poznań 2012, s. 113-114.

${ }^{21}$ The Other Balkan Wars, op. cit., s. 148. Można by oczywiście zwrócić uwagę, iż podczas każdej z wojen popełniane są zbrodnie i okrucieństwa. Autorzy raportu podkreślili jednak brutalność zjawisk zachodzących podczas wojen bałkańskich jako dziedzictwa wielowiekowej nienawiści etnicznej, która była trudna do zrozumienia, gdyż wybuchała między narodami słowiańskimi, niedawnymi sojusznikami w walce z tureckim okupantem. O szczególnej bezwzględności wszystkich stron konfliktu pisał także Lew Trocki w korespondencjach wojennych, L. Trotsky, The war correspondence of Leon Trotsky. The Balkan Wars 1912-13, New York- London - Montreal - Sydney 1991, s. 330 et passim.

22 The Other Balkan Wars, op. cit., s. 10.

${ }^{23}$ Ibidem.

${ }^{24}$ The Other Balkan Wars, op. cit., s. 11.

${ }^{25}$ Baron Constant d'Estournelles stwierdził, iż Albania i Macedonia były bardziej odseparowane od Europy niż Ameryka. Pomiędzy Bałkanami a Europą Zachodnią istniała bowiem cywilizacyjna przepaść. W jego ocenie głównymi winnymi zbrodni popełnianych podczas wojen nie były narody bałkańskie, lecz mocarstwa europejskie, które nie podjęły odpowiednich kroków do ustanowienia pokoju, lecz starały się odnieść korzyści z eskalowania antagonizmów. Tego typu działania stały się charakterystyczne dla następnych konfliktów zbrojnych w tym regionie w XX w., Ibidem, s. 12-19. Na obojętność mocarstw wobec 
żająca się ich bierna postawa wobec tego, co się działo na Półwyspie Bałkańskim, wszystkie te czynniki razem wzięte powodowały eskalację konfliktów narodowościowych, których pełną egzemplifikacją stały się wydarzenia zachodzące w czasie obu wojen bałkańskich, zwłaszcza w Macedonii ${ }^{26}$.

Istotną cechą charakterystyczną tych wojen była także wielka fala migracji. Ludność bowiem nie czekała aż nadejdą wrogowie, tylko opuszczała miejsca zamieszkania w obawie przed zemstą. Największą liczbę uchodźców zanotowano w Macedonii i Tracji. Wkraczające wojska często zastawały wyludnione miejscowości, w których dokonywano zniszczeń, rabunków i podpaleń. W ocenie Komisji Carnegiego, w czasie wojen bałkańskich doszło do czystek etnicznych trudnych do ocenienia. Turcy (muzułmanie) uciekali w obawie przed utratą życia przed chrześcijanami, Bułgarzy przed Grekami i Turkami, Grecy przed Bułgarami, Albańczycy przed Serbami ${ }^{27}$.

\section{Rozwój etnicznej wrogości podczas wojen bałkańskich}

Podczas pierwszej wojny bałkańskiej nienawiść skierowana była szczególnie przeciwko Turkom, na których cierpiące wielowiekową niewolę narody bałkańskie domagały się odwetu. W ciagu stuleci okupacji prawie każda bułgarska wioska w północnej Macedonii doświadczyła cierpienia ze strony przedstawicieli administracji Porty Ottomańskiej. Zemsta była podyktowana nie tylko wcześniejszymi aktami bezprawia popełnionymi przez Turków, ale wynikała też z pogardy wobec innej nacji, wzmacnianej przez religijne uprzedzenia i stereotypowe wyobrażenia na temat Orientu. Nienawiść odczuwano także wobec miejscowych muzułmanów, którzy maszerowali za tureckimi żołnierzami, przyłączając się do rzezi i grabieży. W Tracji bułgarskie zwycięstwo dało możliwość odwetu. Zdaniem Komisji Carnegiego, kroki podjęte przez rząd bułgarski, aby chronić miejscowych muzułmanów, nie były wystarczające. Komisja zwróciła uwagę, że regularna armia nacierająca w kierunku Adrianopola nie pozostawiła za sobą wystarczających garnizonów, które mogłyby zabezpieczyć ludność cywilną. Jej zdaniem, nie dokonano także prób, aby przekształcić oddziały powstańcze w regularne korpusy ${ }^{28}$. Fakty jednak przeczą wnioskom wysuwanym przez międzynarodowych obserwatorów, których wiedza na temat wydarzeń zachodzących na froncie była niepełna. Wystarczy podać przykład Legionu MacedońskoAdrianopolskiego, zwanego także Ochotniczym Korpusem Macedońsko-Trackim,

złożonych problemów narodowościowych na Bałkanach i fakt wykorzystywania tamtejszych narodów w rozgrywkach politycznych wskazywał także L. Trocki, L. Trotsky, op. cit., s. 340-346.

26 J. G. Schurman, The Balkan Wars 1912-1913, Princeton 1914, s. 64-67.

27 The Other Balkan Wars, op. cit., s. 11-12.

${ }^{28}$ Ibidem, s. 72. 
który w październiku 1912 r. rozrósł się do 12 batalionów i liczył ok. 15000 żołnierzy dowodzonych przez oficerów bułgarskich ${ }^{29}$.

Początkowo to przede wszystkim muzułmańska ludność cywilna padała ofiarą gwałtów i grabieży. Amerykański historyk, Justin McCarthy podał, iż podczas wojen bałkańskich zginęło 632 tys. muzułmanów. Liczby te wydają się jednak przesadzone. Bardziej wiarygodne są natomiast dane uwzględnione przez francuskiego historyka, Alexandra Tourmarkine'a, który uznał, iż na 4, 3 mln ludności muzułmańskiej zamieszkującej terytoria wyzwolone przez Serbię, Grecję i Bułgarię - 200 tys. padło ofiarą rozmyślnej przemocy, głodu i epidemii ${ }^{30}$. Podczas I wojny bałkańskiej, zwłaszcza w Macedonii, prowadzona była intensywna propaganda rozprawy z muzułmanami. Od momentu wkroczenia wojsk serbskich wioski muzułmańskie były palone, a ludność wypędzana. Zbrodni tych dokonywali najczęściej w akcji odwetowej chrześcijańscy sąsiedzi, a także oddziały nieregularne, samozwańcze czety, rzadziej wojska $^{31}$. Miały przy tym miejsce publiczne egzekucje, okaleczenia i gwałty ${ }^{32}$. Do największych prześladowań muzułmanów doszło jesienią 1912 r. w Strumicy (południowo-wschodnia Macedonia), najpierw zajętej przez wojska bułgarskie, a następnie serbskie. Sporządzono tam listy proskrypcyjne muzułmanów, którzy byli torturowani, a następnie zabijani. Za morderstwa te, zgodnie z raportem Komisji Carnegiego mieli być odpowiedzialni przede wszystkim Serbowie. Ofiary rabowano z majątku, i tylko niektórzy zdołali wykupić się od śmierci. W miejscowości tej zabito od 3 do 4 tys. osób ${ }^{33}$.

Za zbrodnie wojenne winiono także Bułgarów. W okręgu Pravišta (niedaleko miasta Kawala), zamieszkałym przez 20 tys. muzułmanów oraz 7 tys. Greków, miejscowy biskup grecki zaczął tworzyć rodzaj cywilnej administracji we współpracy z bułgarskimi oddziałami paramilitarnymi, które dokonywały czystek podyktowanych względami religijnymi ${ }^{34}$. W ocenie Komisji Carnegiego, w każdej wiosce zamordowano do $25 \%$ populacji muzułmanów ${ }^{35}$. Do podobnych zdarzeń doszło też w miejscowości

29 Dokładne dane dotyczące liczby batalionów i żołnierzy przedstawiono w raporcie Komisji Ministerstwa Wojny Bułgarii, który powstał na przełomie lat dwudziestych i trzydziestych ubiegłego wieku. Wydaje się, że jest to najlepsze opracowanie poświęcone dziejom wojny 1912-1913, a przynajmniej najwierniej odtwarzające historię tego starcia, Raport na temat tworzenia Macedońsko-Adrianopolskiego Korpusu Pospolitego Ruszenia 25 września (8 października) 1912 r., [w:] J. Rubacha, A. Malinowski, Historia Bułgarii 1870-1915, t. II, Warszawa 2007, s. 101-103.

30 P. Ther, op. cit., s. 114-115.

31 W Macedonii działało ok. 34 czet bułgarskich, podległych przede wszystkim centralnemu komitetowi WMRO, 16 czet serbskich, a także czety greckie, M. Dymarski, op. cit., s. 295.

32 P. Ther, op. cit., s. 116.

33 Komisji skazującej muzułmanów na śmierć przewodniczył serbski dowódca, major Grbić, który jednak później został uwolniony od zarzutów przez sąd w Belgradzie. Z kolei bułgarski sąd wojenny skazał na kary do 15 lat ciężkich robót przywódców bułgarskich oddziałów paramilitarnych, w tym jednego oficera, The other Balkan Wars, op. cit., s. 74.

${ }^{34}$ Okręg Pravišta został zajęty przez czety bułgarskie, na czele których stał Babczew, cywilną administracją kierował natomiast grecki biskup, Ibidem, s. 282-283.

35 Większość zbrodni została dokonana przez greckie oddziały paramilitarne, pod dowództwem popa Panahija, które wchodziły w skład Rady Biskupa. Turcy oskarżyli biskupa o wydawanie wyroków śmierci 
Kilkis (Kukus), gdzie ludność zgromadzono w meczecie, który następnie podpalono, nie oszczędzając kobiet i dzieci ${ }^{36}$. Z kolei w Serres, we wschodniej Macedonii, po wkroczeniu wojsk bułgarskich (6 listopada 1912 r.) zamordowano kilkuset muzułmanów. Aktom bezprawia nie mógł zapobiec konsul austriacki, którego proszono o po$\operatorname{moc}^{37}$. Jedynie miejscowy biskup grecki udzielił schronienia wyznawcom islamu, ratując wielu spośród nich przed niechybną śmiercią ${ }^{38}$.

W latach 1912-1913 z inicjatywy najwyższych władz bułgarskich oraz przedstawicieli bułgarskiej cerkwi prawosławnej została podjęta akcja chrystianizacji Pomaków $^{39}$ (spośród których 400 tys. zamieszkiwało w północnej Macedonii). Jej przebieg nie został dokładnie opisany w literaturze przedmiotu ${ }^{40}$. Wiadomo jednak, że początkowo nakazano członkom muzułmańskiej społeczności, aby zmienili imiona. Następnie zaciagano Pomaków do cerkwi, gdzie byli chrzczeni, i tylko niektórym pozwalano płacić okup, aby mogli tego uniknąć. Z dokumentów Komisji Carnegiego wynika, iż przyjęto plan masowej konwersji Pomaków na chrześcijaństwo, argumentując, że skoro zostali zmuszeni do przejścia na islam, to teraz przemoc może być użyta dla odwrócenia tego procesu. Do wielu okrucieństw dochodziło w związku z wysyłaniem do macedońskich wiosek zdeprawowanych popów, którzy mieli ochrzcić ludność muzułmańską. Członkowie komisji określili ich jako „pijaków i kryminalistów"41.

W Salonikach istniał jeden z największych obozów przejściowych dla tureckich uciekinierów, przez który od początku II wojny bałkańskiej przeszło 135 tys. muzułmanów, pochodzących z różnych części Macedonii. Większość z nich udawała się do Anatolii. Komisja zadała uciekinierom pytanie: dlaczego opuścili swoje domy? Uzyskano odpowiedź, iż przybyli z 26 różnych wiosek, uchodząc w obawie przed Bułgarami, słyszeli bowiem o mordach popełnionych na ludności cywilnej, w tym także na kobietach i dzieciach. Uciekano już w pierwszych dniach wojny, w październiku 1912 r. na południe, w obawie przed wkraczającymi oddziałami serbskimi i bułgarskimi. Strach przed wrogiem, który zadawał śmierć i cierpienie skłonił mieszkań-

na wyznawców islamu, które miał wykonywać bułgarski watażka, Babczew. Dowody jednak wskazują, że nie zabijał i nie gwałcił on muzułmańskich kobiet, a nawet ratował je przed śmiercią. Jedną z wybawionych była córka oficera żandarmerii, który przebywał w Konstantynopolu. Babczew uzyskał dla niej paszport, aby mogła bezpiecznie wrócić do rodziny, The Other Balkan Wars, op. cit., s. 282-284.

36 Ibidem, s. 74.

37 K. Stępnik, op. cit., s. 87.

38 J. Mc Carthy, Death and Exile. The ethnic cleansing of Ottoman Muslims 1821-1922, Princeton 1995, s. 147.

39 Pomacy - bułgarskojęzyczni muzułmanie osiedleni w Rodopach i zachodniej Tracji oraz słowiańskojęzyczni muzułmanie w Macedonii, Albanii i Turcji. W okresie panowania Imperium Ottomańskiego na Bałkanach Pomacy służyli w tureckiej armii, gdzie byli znani z fanatycznego ducha walki, M. Lubańska, Pomacy, [w:] Bałkany etnokulturowe podłoże konfliktów, red. W. Konarski, A. Koseski, Pułtusk 2006, s. 233.

40 Ibidem, s. 239.

41 The Other Balkan Wars, op. cit., s. 78, s. 155-157. 
ców do opuszczania domów ${ }^{42}$. Z danych władz w Stambule wynikało, że 441 tys. uchodźców osiedliło się we wschodniej Tracji oraz zachodniej Anatolii ${ }^{43}$.

Bułgarski rząd podjął wysiłek, aby osądzić akty bezprawia popełnione na wyznawcach islamu. Do lutego 1913 r. bułgarskie sądy wojenne w Macedonii wydały wyroki na 10 osób w sprawie morderstw, 8 skazano za rabunek, natomiast 2 za gwałt. Co prawda, te statystyki nie odzwierciedlają skali problemu, pokazują jednak, że władze w Sofii nie pozostawały obojętne wobec przestępstw wojennych ${ }^{44}$.

Rozpętana spirala nienawiści sprawiła, że także i Turcy dopuszczali się licznych zbrodni. Jeden z członków Legionu Macedońskiego przedstawił relację świadczącą o przemocy i okrucieństwach dokonanych przez Turków na ludności cywilnej, w tym kobietach i dzieciach ${ }^{45}$. Podczas I wojny bałkańskiej podczas ucieczki spod Lozengradu wojska tureckie popełniły wiele zbrodni, we wsi Asboa eksterminując całą ludność chrześcijańską. W miejscowościach Czugara i Sandżik dokonali aktów barbarzyństwa, obcinając nosy i uszy oraz wyłupiając oczy mieszkańcom ${ }^{46}$. W trakcie bitwy pod Bunar- Hissar Turcy zamordowali wszystkich rannych żołnierzy pozostawionych w ambulansie przez wycofujących się Bułgarów ${ }^{47}$.

Dzięki doniesieniom prasowym można uświadomić sobie jak wyglądał powrót wojsk tureckich do Adrianopola, w sierpniu 1913 r. W zemście uczestniczyły przede wszystkim oddziały nieregularne, jak też zwykłe bandy rabusiów i podpalaczy. Większość gazet europejskich i amerykańskich była wypełniona relacjami na temat dokonywanych czystek etnicznych i masowych migracji. Zgodnie z tymi opisami, do represji doszło także w Konstantynopolu, którego chrześcijańscy mieszkańcy obawiali się rzezi, zagrażającej im ze strony pokonanego i zdemoralizowanego wojska tureckiego. Reporterzy współczuli uciekinierom, których wioski zostały zrównane z ziemią, określając stolicę imperium tureckiego jako „zbiorowisko przerażającej nędzy"*48. W wyniku prześladowań ze strony Turków w lipcu 1913 r. zbiegło z Tracji ok. 20 tys. Greków i 50 tys. Bułgarów ${ }^{49}$.

Do zbrodni wojennych popełnionych przez Turków doszło także we Wschodniej Macedonii. W dolinie Strumy tureckie wojsko i bandy rozbójnicze, wycofując się, niszczyli bułgarskie wioski, a opuszczając Demir-Hissar wpędzili 200 chrześci-

42 Podobne obozy wizytowano w Bułgarii, gdzie zgromadzono 111560 uciekinierów, spośród których 50 tys. przybyło z Macedonii Wardarskiej i Egejskiej, ratując się przed Serbami i Grekami. Emigranci zamieszkiwali 108 miejscowości, które w pośpiechu opuścili, Ibidem, s. 151-154.

43 J. McCarthy, The Ottoman Peoples and the End of Empire, London 2001, s. 92.

${ }^{44}$ The Other Balkan Wars, op. cit., s. 76.

45 Institut za Woenna Istorija, Odrin 1912-1913, Spomeni, red. M. P. Jonow, Sofia 1983, s. 18-20.

${ }^{46}$ J. Lipkowski, Wojna na Bałkanach przez naocznego świadka i uczestnika wojny, WarszawaLublin-Łódź-Kraków 1915, s. 163.

47 Ibidem.

${ }^{48}$ K. Stępnik, op. cit., s. 94-95.

49 E. Znamierowska- Rakk, Sprawa Tracji Zachodniej w polityce bułgarskiej (1919-1947), Warszawa 1991, s. 22. 
jan do cerkwi, którą następnie podpalilii ${ }^{50}$. Przy czym, największym okrucieństwem charakteryzowały się oddziały nieregularne, tzw. baszybuzucy ${ }^{51}$. W opinii Józefa Lipkowskiego, uczestnika wojen bałkańskich, Turcy spalili co najmniej dwa razy tyle wsi i wymordowali trzy razy więcej ludności niż armie sojusznicze ${ }^{52}$.

$\mathrm{Z}$ relacji przedstawionych przez Komisję Carnegiego wynikało jednak, że największa skala prześladowań dotknęła przede wszystkim ludność muzułmańską. Tego obrazu Macedonii czasów wojny nie można jednak uznać za obiektywny m. in. ze względu na oddziaływanie propagandy tureckiej, która chciała zwrócić uwagę społeczności na Zachodzie na rzekomą wielką skalę czystek popełnianych na wyznawcach islamu, których należało wziąć w obronę. Trzeba także pamiętać, że Komisja Carnegiego działała przede wszystkim po opuszczeniu Macedonii przez oddziały tureckie, dostrzegała, więc, naruszenia prawa dokonane głównie przez armie sojuszników, nie mogła natomiast właściwie ocenić skali przestępstw, które zostały popełnione przez Turków.

\section{Eskalacja walk chrześcijan ze współwyznawcami}

Należy podkreślić, że podczas II wojny bałkańskiej państwa chrześcijańskie walczyły ze sobą z taką samą zaciekłością jak wcześniej z Imperium Ottomańskim. Bułgarzy okupowali kraj, w którym populacja była w większości grecka i muzułmańska (turecka). Oskarżenia wysuwane przez Greków przeciwko Bułgarom zostały przekazane $\mathrm{w}$ relacjach korespondentów wojennych, którzy dobrze byli przyjmowani przez Greków, ale nie najlepiej przez Bułgarów, co może jednak świadczyć o braku obiektywizmu w wielu ówczesnych korespondencjach.

Do szczególnych okrucieństw wojennych doszło w mieście Doxato (leżącym pomiędzy Dramą a Kavalą), w którym większość stanowili Grecy. Oddziały bułgarskie użyły muzułmanów do walki przeciwko ludności greckiej. Wyjątkową bezwzględnością mieli oznaczać się Pomacy, którzy zabijali napotkane na ulicach kobiety i dzie$\mathrm{ci}^{53}$. Jeden ze świadków, mającej tam miejsce masakry uznał, iż było to „miasto śmierci”, w którym wszędzie „czuło się zapach krwi i rozkładających się ciał”. Przeżyło tylko kilku mieszkańców, zaś liczbę ofiar oceniono na 600 osób $^{54}$.

Za akty bezprawia na ludności cywilnej w Serres (o którym już była mowa) odpowiedzialni byli zarówno Bułgarzy, Grecy, jak i muzułmanie. Najpierw Bułgarzy zamordowali jeńców i przedstawicieli władz tego greckiego (pod względem etnicz-

${ }^{50}$ A. Rjabinin, Balkanskaja vojna, [w:] Malyje vojny pjervoj poloviny XX vieka. Balkany, Moskva 2003, s. 218-219.

${ }^{51}$ J. Lipkowski, op. cit., s. 162

52 Ibidem, s. 165.

${ }^{53} \mathrm{~W}$ ocenie komandora Cardale, oficera brytyjskiej marynarki w greckiej służbie, muzułmanie działali pod dowództwem bułgarskich oficerów. Niewątpliwie więc strona bułgarska była odpowiedzialna za dokonane przestępstwa i zbrodnie, The Other Balkan Wars, op. cit., s. 81-82.

${ }^{54}$ Ibidem, s. 285-286. 
nym) miasta, którzy nie mogli zapłacić okupu. Po ewakuacji wojsk bułgarskich natomiast władzę przejęli Grecy i muzułmanie. Pojmali oni 200-250 Bułgarów (4 kobiety), których oskarżyli o bunt, a następnie w bestialski sposób zamordowali ${ }^{55}$. Po pewnym czasie wróciły wojska bułgarskie (wraz z Pomakami), aby zemścić się za zbrodnie popełnione przez Greków. Splądrowano wówczas grecką dzielnicę miasto, niszcząc większość budynków mieszkalnych ${ }^{56}$.

Do podobnych wydarzeń doszło we wspomnianej już miejscowości Demir -Hissar, gdzie w wyniku prowokacji ze strony Greków i Bułgarów nastapił odwet armii greckiej na ludności bułgarskiej ${ }^{57}$. Grecy zabijali bezbronnych Bułgarów, natomiast po ponownym opanowaniu miasta przez Bułgarów wzięto odwet na ludności greckiej. Obydwie nacje przygotowały listy ofiar, ze strony bułgarskiej miało to być 250 osób, po stronie Greków natomiast 71 (w tym kobiety i dziecis ${ }^{58}$ ).

W ocenie Komisji Carnegiego, wydarzenia w Doxato, Demir-Hissar i spalenie Serres stawiają w stan oskarżenia przede wszystkim Bułgarów, którzy mścili się z powodu rzekomych krzywd doznanych od Greków. Nie można było jednak potwierdzić oskarżeń wysuwanych przez Greków, że Bułgarzy mieli opracowany plan eksterminacji ludności greckiej ${ }^{59}$.

Należy podkreślić, że w czasie wojen bałkańskich miała miejsce bodajże pierwsza $\mathrm{w}$ historii konfliktów zbrojnych wojna medialna. Jednym $\mathrm{z}$ jej przejawów było celowe dezinformowanie oraz stosowanie na szeroką skalę tzw. czarnej propagandy, która miała ukazywać przeciwników w niekorzystnym świetle. Ponadto inscenizowano walki, jakie rzekomo toczono na froncie. Znany był z tego przede wszystkim sztab armii greckiej, który pozwalał reporterom na manipulowanie faktami. W ten sposób np. wyreżyserowano zdobycie Salonik, chociaż w chwili kapitulacji miasta, oddział grecki był oddalony o $17 \mathrm{~km}$ od miasta ${ }^{60}$.

Prasa grecka tendencyjnie przedstawiała Bułgarów, jako barbarzyńców żyjących z dala od cywilizacji. Popularne były plakaty i wierszyki, w których opisywano ich jako morderców. Znany rysunek wojenny przedstawiał greckiego żołnierza, który wydłubuje oczy bułgarskiemu jeńcowi. W opisie można było przeczytać, że nienawiść

55 Ibidem, s. 291-292.

${ }^{56}$ Grecy nie znaleźli dowodów, że spalenie ich dzielnicy stanowiło celowe działanie sztabu bułgarskiego. Zdaniem Komisji Carnegiego, wydarzenia w Serres były w jednakowym stopniu kompromitujące zarówno dla Greków, jak i Bułgarów, Ibidem, s. 92.

${ }^{57}$ M. Dymarski, op. cit., s. 297.

58 Przypuszczano, że w Macedonii zostało zabitych czterech biskupów greckich, ale informacje te nie potwierdziły się. Bułgarzy przyznali się do zastrzelenia jednego biskupa, który pierwszy otworzył do nich ogień. Grecy twierdzili, że jego ciało zostało okaleczone na rozkaz kapitana Bostanova. Strona bułgarska zaprzeczyła jednak istnieniu takiego oficera. Należy podkreślić, że biskupi greccy, jak i bułgarscy byli uznawani za głowy swoich społeczności, często także pozostawali w bliskich związkach z oddziałami buntowników, The Other Balkan Wars, op. cit., s. 93.

${ }^{59}$ Ibidem.

${ }^{60}$ Korespondenci wojenni w sztabach armii greckiej dysponowali nieograniczonymi możliwościami działania, co nie mogło mieć miejsca ze względów cenzuralnych w Bułgarii i Serbii, K. Stępnik, op. cit., s. 73 . 
Greków mogłaby ugasić tylko krew tych „potworów” ${ }^{\prime 1}$. Ponadto dyplomaci greccy w wielu europejskich stolicach opowiadali jakoby w kieszeniach wziętych do niewoli żołnierzy bułgarskich znaleziono palce i uszy kobiece. Historie te rozpowszechniali dziennikarze, którzy usłyszeli je od greckich żołnierzy ${ }^{62}$. Oczywiście, nie miały one nic wspólnego z prawda, świadczyły jednak na niekorzyść strony greckiej, która nie szczędziła wysiłków, aby naruszyć wizerunek przeciwnika. Identyczne zjawiska związane $\mathrm{z}$ wojną propagandową będą miały miejsce w następnych starciach na Bałkanach w XX w., gdzie do walki medialnej zaangażowane zostaną profesjonalne firmy dziennikarskie i marketingowe, kreujące m. in. obraz zbrodniczych Serbów czy Jugosławii pod rządami Slobodana Miloševicia, która miała hamować rozwój postępu i demokracji na Bałkanach.

\section{Proces serbizacji i hellenizacji ludności macedońskiej}

Zarówno żołnierze serbscy, jak i greccy wyzwalający Macedonię, byli przekonani, że napotkają tam rodaków, mówiących tym samym językiem. Ich spotkanie z rzeczywistością było jednak odmienne od wcześniejszych wyobrażeń. Zaskoczyła ich przede wszystkim niechęć, którą przejawiała ludność w stosunku do wkraczających wojsk. Serbowie sądzili, iż wroga postawa, jaką reprezentowali wobec nich mieszkańcy Macedonii, stanowiła rezultat agitacji bułgarskiej ${ }^{63}$. Co prawda, w pierwszych dniach po wyzwoleniu spod panowania tureckiego pojawiła się wdzięczność dla Greków i Serbów. Namawiali do niej zwłaszcza działacze macedońskiego ruchu rewolucyjnego, zachęcając do entuzjastycznego przyjmowania pogromców Turków. Na początku wojny 18 października 1912 r. wydali odezwę, w której można było przeczytać: „Bracia: - wasze cierpienia i krzywdy dotknęły nasze bratnie dusze. Poruszeni świętym obowiązkiem braterskiego współczucia, przybyli żołnierze serbscy i greccy, by uwolnić was spod tureckiego jarzma. Niczego więcej nie pragna, jak tylko przywrócić pokój i porządek na naszych rodzinnych ziemiach. Przywitajcie tych dzielnych rycerzy, pokrywając drogę, po której maszerują, kwiatami wolności i chwały. I okażcie się wspaniałomyślnymi dla tych, którzy jeszcze wczoraj byli waszymi panami. Jako prawdziwi chrześcijanie nie odpłacajcie złem za zło! Niech żyje wolność! Niech żyje wyzwoleńcza armia!’. Pod wpływem tych agitacji tłumy początkowo wiwatowały na cześć Greków i Serbów, wkrótce jednak ich uczucia uległy diametralnej zmianie. Bułgarska gazeta w Salonikach „Byłgarine” podawała liczne przykłady wykorzystywania i terroryzowania ludności, sugerując, iż nie była to wojna o wyzwolenie, lecz o zdobycie nowych terytoriów ${ }^{64}$. Serbowie w wielu przekazach prasowych często byli przedstawiani jako megalomańscy agresorzy, naród z natury skłonny do

\footnotetext{
61 The Other Balkan Wars, op. cit., s. 96-97.

62 Ibidem, s. 94.

${ }^{63}$ A. Malinowski, Kwestia macedońska w Bulgarii w latach 1878-1918, Toruń 2006, s. 146.

${ }^{64}$ Greckie władze wkrótce zakazały działalności tej gazety, Ibidem.
} 
fantastycznych urojeń, który sam siebie uważał za powołanego do historycznej misji na Bałkanach, jak również do hegemonii nad wszystkimi ludami bałkańskimi ${ }^{65}$.

Po zakończeniu wojen bałkańskich Macedonia Wardarska i Macedonia Egejska zostały poddane serbizacji i hellenizacji. Polityka prowadzona przez władze serbskie i greckie doprowadziła do usunięcia macedońskich przywódców intelektualnych, religijnych i niepodległościowych. Szczególnie nauczyciele i duchowni bułgarscy uważani byli za niebezpiecznych konspiratorów, których należało się pozbyć. Z tych powodów szkoły poddawano systematycznej inwigilacji, zakazano także czytania książek w języku bułgarskim. Pierwszym krokiem Serbów i Greków po przybyciu do jakiekolwiek miejscowości było zamykanie szkół. Kolejny etap wiązał się z postawieniem nauczycielom ultimatum, że w razie odmowy nauczania w języku serbskim lub greckim ich działalność nie będzie dłużej tolerowana. Zdarzało się, że odsyłano ich do Bułgarii, ale częściej osadzano w więzieniach w Salonikach lub Skopje.

W literaturze przedmiotu znane są liczne przypadki prześladowań i dyskryminacji na tle narodowościowym i religijnym. W Tetovie wszyscy popi i przedstawiciele lokalnej władzy z okolicznych wiosek zostali zebrani w serbskim klasztorze. Starano się ich przekonać, że są Serbami, zmuszano, aby wysłali wiernopoddańczy telegram do króla Piotra ${ }^{66}$. W prasie serbskiej ukazywały się optymistyczne artykuły, w których pisano, że w miastach śpiewa się tylko po serbsku, tańczy się tylko tańce serbskie, nie ma już mieszkańców, którzy nazywaliby siebie Bułgarami. Z innego miasta, Monastyru informowano, że zostało ono otoczone kordonem wojska, bowiem Serbowie obawiali się rozruchów wśród Bułgarów. Represje rozciąnięto na ludność cywilną, np. młodzi ludzie pomiędzy 19. a 30. rokiem życia nie mogli opuszczać kraju. Pod karą grzywny zmuszano dzieci do chodzenia do serbskich szkół, ponadto bez zgody władz rodzicom nie wolno było wysyłać potomstwa za granicę (tj. do Bułgarii) w celach edukacyjnych ${ }^{67}$.

Prześladowania spotkały także przedstawicieli Narodowego Kościoła Bułgarskiego i jego dostojników. Żądano od nich, by swe nabożeństwa celebrowali w języku serbskim lub greckim. Ponadto zabraniano utrzymywania jakichkolwiek stosunków $\mathrm{z}$ wiernymi, a najmniejsze nieposłuszeństwo traktowano jako polityczną propagandę i zdradę. Biskupowi Neofitowi z Weles zakazano wykonywania posług religijnych, gdyż odmówił oddzielania podczas modlitwy imienia serbskiego króla Piotra od imion innych władców oraz w czasie mszy używał kolorów kojarzących się z bułgarskimi barwami narodowymi ${ }^{68}$. Także inni biskupi byli traktowani jak więźniowie we własnym domu, ich współpracowników aresztowano albo wypędzano. Do takich wypadków dochodziło np. w Monastyrze. Z kolei biskup Boris z Ochrydy został oskarżony o przygotowywanie buntu przeciwko Serbom. W efekcie prześladowań

\footnotetext{
${ }^{65}$ K. Stępnik, op. cit., s. 146.

${ }^{66}$ The Other Balkan Wars, op. cit., s. 171.

${ }^{67}$ Ibidem, s. 183.

${ }^{68}$ A. Malinowski, op. cit., s. 147.
} 
wszyscy wysocy dostojnicy kościoła zostali zmuszeni do wyjazdu do Salonik i w ten sposób praktycznie przestał istnieć kościół bułgarski w Macedonii ${ }^{69}$.

Na miejscową ludność wywierano natomiast presję, domagając się, aby wyrzekła się swego pochodzenia, przyznając, iż należy do narodowości serbskiej lub greckiej. Z relacji jednego z biskupów wynikało, iż serbscy popi i nauczyciele „odwiedzali” wraz z żołnierzami macedońskie wioski, zmuszając mieszkańców do podpisania dokumentów, iż są Serbami. Jeśli ktoś próbował się sprzeciwić, był torturowany ${ }^{70}$. Każdy, kto identyfikował się z nacją bułgarską narażał się na represje, włącznie z utratą życia. W Macedonii Wardarskiej Serbowie utworzyli okręgi, grupujące poszczególne miejscowości, w ramach których powołali do życia bardzo dobrze działającą sieć wywiadowczą ${ }^{71}$. Każdy, kto źle mówił o Serbach lub w niekorzystnym świetle przedstawiał ich rządy, musiał być świadom czekających go represji.

Grecy postępowali w Macedonii podobnie jak Serbowie, stosując na szeroką skalę politykę wynaradawiania. Ich działania określano nawet często, jako mniej humanitarne niż serbskie, gdyż traktowali mieszkańców wyjątkowo brutalnie, często zadając pytanie: „czy ci brudni Słowianie, są rasą ludzką?” Żołnierze greccy działali zgodnie z prostą zasadą. Zjawiali się w domu rodziny bułgarskiej, mówiąc: „pieniądze albo życie" 72 . Najgorsze prześladowania miały miejsce w Salonikach, gdzie Grecy torturowali i głodzili osoby podejrzane o współpracę z oddziałami bułgarskimi. Podobnie traktowano duchownych, którzy sprzeciwiali się hellenizacji ${ }^{73}$.

Pewien grecki oficer w wiosce Krupicza zapytał chłopa, jak długo był Bułgarem. W odpowiedzi usłyszał, że zawsze. Wtedy nakazał mu by, aby stał się Grekiem. Następnie okazał mu nadzwyczajną łaskę, nie pozbawiając go życia. W innej wiosce, Gorno-Nestrame, gdy na pytania ludność odpowiadała po bułgarsku, oficer grecki zakazał używania tego języka, twierdząc, iż znajdują się na terytorium państwa greckiego. W kilku innych miejscowościach zadawano jeszcze bardziej dziwne pytania. Dotyczyły one bowiem tego, czy mieszkańcy są chrześcijanami czy Bułgarami. W Macedonii Egejskiej mieszkańcom dawano do podpisu petycję z żądaniem przyłączenia tych terenów do Grecji ${ }^{74}$. W liście napisanym w grudniu 1912 r. z wioski Dembesi (Kastoria) można było przeczytać: „Pierwszą czynnością, jaką podjęli oficerowie greccy, jak również szeregowi żołnierze, było sprawdzenie czy ludność zamieszkująca tę wioskę, to Grecy czy Bułgarzy. Jeśli okazywali się narodowości bułgarskiej, wtedy oficerowie rozkazywali chłopom, by ponownie stali się Grekami i dopiero wtedy pozwalano im żyć w spokoju"75.

Wprowadzenie administracji greckiej i serbskiej w Macedonii było nacechowane przemocą i dążeniem do zmiany struktury etnicznej tego terytorium. Członkowie

\footnotetext{
${ }^{69}$ The Other Balkan Wars, op. cit., s. 168.

${ }^{70}$ A. Malinowski, op. cit., s. 148.

${ }^{71}$ Ibidem, s. 150.

72 The Other Balkan Wars, op. cit., s. 192.

73 Ibidem, s. 189.

${ }^{74}$ A. Malinowski, op. cit., s. 150.

${ }^{75}$ Ibidem.
} 
Komisji Carnegiego zwrócili uwagę, że część tamtejszej ludności tęskniła za czasami tureckimi, marząc o powrocie niedawnych okupantów. Paradoksalnie, w ocenie komisji, wojny bałkańskie pokazały, iż więcej było na tych ziemiach pokoju, kiedy znajdowały się one pod władzą Imperium Ottomańskiego ${ }^{76}$. Członkowie komisji nie wzięli jednak pod uwagę wydarzeń, jakie rozgrywały się w Macedonii w pierwszej dekadzie XX w., kiedy ludność chrześcijańska została poddana permanentnym represjom ze strony Turcji, co wielokrotnie wywoływało interwencję mocarstw. Z pewnością wojny bałkańskie rozbudziły nienawiść etniczną oraz otworzyły kolejne obszary konfliktogenne. Pojawili się też „nowi” wrogowie, którymi często stawali się przedstawiciele tej samej religii, lecz innej grupy etnicznej. Jak stwierdziła prof. Irena Stawowy - Kawka, przyłączenie do Serbii Macedonii Wardarskiej spowodowało niezadowolenie ludności, co doprowadziło do wybuchu we wrześniu 1913 r. powstania przygotowanego przez ludność albańską i macedońską w okolicach Ochrydu, Strugi i Debaru. Zostało ono jednak stłumione przy pomocy oddziałów greckiej armii ${ }^{77}$.

\section{Zakończenie}

Należy podkreślić, iż w rezultacie wojen bałkańskich wykształcił się nacjonalizm określany jako Wschodni i „gorący”. Nowo powstałe państwa nie posiadały wielkiego doświadczenia politycznego, dlatego też na ich terytoriach mógł on wystapić z wielką intensywnością. Prof. Henryk Batowski zauważył, że podbite przez Turków narody bałkańskie dążyły nie tylko do zdobycia niepodległości, ale zamierzały też zagarnąć ziemie należące do sąsiadów, co stało się główną przyczyną rozwoju konfliktów narodowościowo-etnicznych na Bałkanach ${ }^{78}$. Ten ewoluujący w czasie wojen bałkańskich nacjonalizm Wschodni znalazł kontynuację w kolejnych antagonizmach w XX w. Zapoczątkowane w czasie wojen bałkańskich czystki etniczne na szeroką skalę stały się jednym z jego przejawów. Słuszna jest ocena prof. Adama Koseskiego, zgodnie z którą współczesne konflikty etniczne na Bałkanach polegają na tym, iż przeciwnicy dążą do dominacji i podporządkowania drugiej strony oraz jej zniszczenia, a nawet unicestwienia ${ }^{79}$. Trzeba więc uznać, że są to konflikty w swoich celach zdeterminowane i permanentne, ponadto w historycznej perspektywie nieskończone.

Z dozą krytycyzmu należy odnieść się natomiast do poglądów badaczy na Zachodzie, zgodnie z którymi historia Słowian Południowych przepełniona jest plemienną nienawiścią, zakorzenioną $\mathrm{w}$ ich psychice i światopoglądzie. Sprawia ona, że dzieje tych narodów charakteryzują się przemocą oraz chęcią podboju sąsiednich ziem. Narody bałkańskie na Zachodzie oceniane są więc często przez pryzmat etnicz-

76 The Other Balkan Wars, op. cit., s. 15.

77 I. Stawowy- Kawka, Historia Macedonii, Wrocław-Warszawa-Kraków 2000, s. 170.

${ }^{78}$ H. Batowski, Zagadnienia bałkańskie, Kraków 1939, s. 21.

${ }^{79}$ A. Koseski, Bałkańskie konflikty etniczne w latach dziewięćdziesiatych XX wieku, „Rocznik Nauk Politycznych" 2000, nr 1 (2), s. 82. 
nych uprzedzeń, opartych na przeświadczeniu, że na Bałkanach żyją społeczeństwa, których psychika przesiąknięta jest prymitywną nienawiścią i chęcią zemsty, odmienne od cywilizowanych narodów Europy Zachodniej ${ }^{80}$. Koresponduje to z poglądem badacza Elie Kedourie i jego „teorią mrocznych bóstw”, zgodnie z którą nacjonalizm może prowadzić do odrodzenie się atawistycznego kultu własnej krwi i własnego terytorium ${ }^{81}$. Z takim zjawiskiem wielokrotnie spotykamy się na Bałkanach. Czym bowiem są konflikty zbrojne, do których doszło między narodami Słowian Południowych w czasie II wojny bałkańskiej, II wojny światowej, czy wojny domowej w Jugosławii?

Tego rodzaju wnioski badawcze wymagająjednak podjęcia szerszej debaty w gronie znawców problematyki. Choć i dziś możemy stwierdzić, że konflikty etniczne na Bałkanach nie wygasły, występując z całą bezwzględnością pod koniec XX w. podczas wojny domowej związanej z rozpadem Jugosławii. W raporcie Komisji Carnegiego, pojawiło się określenie „megalomania narodowego ideału”, co stanowi słuszną diagnozę bałkańskich realiów, gdzie trudno jest znaleźć konsensus między podmiotami stosunków międzynarodowych i nie tylko. W obliczu ekstremalnych, nacjonalistycznych samouwielbień i wzajemnych podejrzeń nie wydaje się, aby kiedykolwiek było możliwe pojednanie ${ }^{82}$. Takie podejście towarzyszyło narodom i grupom etnicznym w czasie wojen bałkańskich, kiedy każdy walczył w imię realizacji partykularnych celów. Jak zauważył H. L. Kostanick: „,w okresie przyjaźni między krajami bałkańskimi problemy terytorialne pozostają w uśpieniu i są czasowo rozwiązywane na drodze pokojowej lub tolerowane. Ale w okresie kryzysu zarówno lokalne, jak i międzynarodowe aspiracje terytorialne odżywają i rozpoczyna się nowa fala w walce o terytoria" ${ }^{83}$. Czy Bałkany w XXI wieku pozostaną areną nacjonalistycznych uprzedzeń, kolejnych sporów i konfliktów? Oto pytanie, na które nadal trudno dać jednoznaczną odpowiedź.

80 Ta plemienna nienawiść, charakterystyczna dla narodów bałkańskich, była szczególnie widoczna w historii Bośni i Hercegowiny, R. J. Donia, Vještački nalaz, „Časopis za suvremenu povijest”, br.1, 2004, s. 76.

${ }^{81}$ E. Kellner, op. cit., s. 234-235.

${ }^{82}$ The Other Balkan Wars, op. cit., s. 11.

${ }^{83}$ H. L. Kostanick, op. cit., s. 9. 


\title{
THE BALKAN WARS 1912-1913 AS A CAUSE OF THE DEVELOPMENT OF "HOT NATIONALISM" IN THE BALKANS. THE OUTLINE OF THE PROBLEM
}

\begin{abstract}
Summary
The aim of this paper is to examine the origin of "hot nationalism" in the Balkans. Undoubtedly, this kind of nationalism was the final element of the Balkan Wars, that erupted in 1912. The author presents the hypothesis that all Balkan conflicts have in common many factors. First of all, they were leading to develop of the modern nationalism. The ethnic cleansing, which were conducted during the Balkans Wars became the origin of the next Balkan conflicts in XX and XXI centuries. Furthermore, the most important acts of cruelty, violations, rapes, murders are being described along with the overall as it is being manifested in the case of Macedonia. The crucial source of this article constitutes The other Balkan Wars. A 1913 Carnegie Endowment inquiry in retrospect with a new introduction and reflections on the present conflict by George F. Kennan, written in Washington 1993, based on Carnegie Commission Report (1914), whose authors emphasized that "hot nationalism" manifested itself on the field of battle, drew on deeper traits of character inherited, presumably, from a distant tribal past, a tendency to view the outsider, with dark suspicion, and to see the political opponent as a fearful and implacable enemy to be rendered harmless only by total and unpitying destruction. The author asks the question if the "Eastern nationalism", the most ferocious nationalism, still causes the threat to the security not only in the South Europe but also in the Old Continent?
\end{abstract}

